\title{
Success Factors for Baitulmal Management during the Reign of Caliph Umar ibn Abdul Aziz
}

\author{
Radieah Mohd Nor \\ Centre for Global Sustainability Studies (CGSS), Universiti Sains Malaysia, Penang, Malaysia \\ Email: radieah@usm.my
}

Received 20 March 2015; accepted 7 May 2015; published 8 May 2015

Copyright (C) 2015 by author and Scientific Research Publishing Inc. This work is licensed under the Creative Commons Attribution International License (CC BY). http://creativecommons.org/licenses/by/4.0/

(c) (i) Open Access

\begin{abstract}
In general, baitulmal is a store treasury or property house which manages all properties and financial resources of Muslims community. Therefore, primary responsibility of baitulmal is managing assets and finances that are owned by and entrusted to Muslims community such as zakat, wakf, usyur, khaaraj and other sources that are permitted by Islamic law as an effort to reduce poverty and for socio-economic development. This article intends to examine the management of baitulmal during the period of Caliph Umar ibn Abdul Aziz. This is important because Caliph Umar ibn Abdul Aziz has made several revolutions throughout his reign. Based on textual analysis, six critical success factors for treasury management during his reign have been identified. The factors are healthy environment for economic growth, strengthening of the baitulmal, stimulating and boosting the business sector, creating new rules for the agricultural sector, giving more focus to the general fund stored in the treasury and the last factor is vigilance with the use of the national treasury.
\end{abstract}

\section{Keywords}

Management, Baitulmal (Treasury), Caliph Umar ibn Abdul Aziz, Success Factors

\section{Introduction}

Caliph Umar ibn Abdul Aziz was in reign for a period of only two years and five or six months, but the caliph has been successful in revolutionising almost all the systems within the field of power that he holds as a caliph. Those fields were political, economic, education and social [1]. People lived peacefully under his reign [2]. As a proof, the citizens of Basra are very happy whenever the messenger from the caliph comes to their area as they 
know, they will be awarded with good news from the caliph. Once, the messenger comes in tears. The tears also bring tears to the whole citizens of Basra. The messenger went inside the Basra Mosque and read aloud the letter which told the news of the death of Caliph Umar ibn Abdul Aziz.

The event showed that Caliph Umar ibn Abdul Aziz was a caliph who really performed his duty to such extend that makes people love his reign so much, unlike the previous caliphs who were guilty of fraud particularly when handling assets in treasury. This paper will try to discover the factors that determine the successful treasury management undertaken by the caliph. However, this paper is only a preliminary discussion of the success factors as it will require a more in-depth research and wider scope of discussion to fully explain these factors.

The success factors that will be discussed in this paper are first, the creation of healthy environment for economic growth; second, strengthening of baitulmal's; third, stimulating and boosting the business sector; fourth, creating new rules for agricultural sectors; fifth, focus on the general fund stored in the baitulmal; sixth, vigilance toward the use of the baitulmal's funds. These six factors will be discussed in the following sub-topic.

\section{Creation of a Healthy Environment for Economic Growth}

The attitude of predecessor of Caliph Umar ibn Abdul Aziz was a burden to the people. The rich keep getting richer and the poor became poorer. The situation was recognized by Caliph Umar ibn Abdul Aziz when he expressed his dissatisfaction over the way Caliph Suleiman ibn Abdul Malik rules. The way Caliph Suleiman ibn Abdul Malik rules has made the people lives in economic systems which unfavorable to them [3]. When Caliph Umar ibn Abdul Malik was appointed as caliph to replace Caliph Suleiman ibn Abdul Malik, he has created a healthy environment for economic growth for the people and their country as well. The system has profited the people and eventually has increased baitulmal's funds [3].

Among the enhancements that were implemented was prohibiting the governors and government employees to do monopolies of national's assets and wealth. In addition, the caliph also forbade the governors and government's officials from confiscating and seizing the citizen's assets unjustly [4]. Properties that were confiscated unjustly before he enforces the law were reinstated to the original owners. He investigated and makes it public so that people who were oppressed before will come forward to reclaim their properties. However, if the identity of the owners remained unknown, the properties were to be owned and used properly for the citizens [1].

Moreover, Caliph Umar ibn Abdul Aziz also builds infrastructure such as bridges, public transportation, digs a few wells, builds roads and drainage systems (digging the land to create man-made river). In developing these infrastructures, Caliph Umar ibn Abdul Aziz ordered it without collecting funds from the people. The instructions were issued so that the governors and civil servants will not taking advantages of the people by charging taxes for the construction [1].

The caliph effort has indirectly makes his people began to be involved in business and trade. The increase in revenue of the trading has increased the baitulmal's fund too, especially funds that come from zakat and usyur ${ }^{1}$. These have resulted in many zimmi ${ }^{2}$ to embrace Islam.

The creation of a healthy environment for economic growth has impacted by increasing the treasury funds. The wisdom of providing this enhanced system was due to the acquisition of knowledge by the caliph. The caliph also was a scholar who can issue fatwas. Thus, his status as a caliph has made it easier for him to enforce the fatwas in his ruling system. Such situation has made it easier to strengthen the treasury management during his reign.

\section{Strengthening of Baitulmal Fund}

Islamic funds deposited in the treasury during his time were zakat, ufti ${ }^{3}$, khaaraj $^{4}$, usyur, a fifth of ghanimah ${ }^{5}$, and $f^{\prime}{ }^{\prime} e^{6}$. Overall, the funds from zakat was increased due to the increased of revenue from the business, trades and agricultural sectors. Increased of zimmi who converted to Islam also contributes in increasing the zakat's fund as there were more Muslim who can contribute zakat. A new fatwas issued by the caliph regarding the expansion of the law to pay zakat for the trades of fish and honey also led to an increase in zakat funds.

${ }^{1}$ The fee that was charged from the business done by the non-Muslim whether zimmi (non-Muslim that cannot be attacked) or harbi (the non-Muslims that Muslims can fight) when they cross national borders of Muslim’s country.

${ }^{2}$ Non-Muslim population which was under the rule of Islam.

${ }^{3}$ Tax that were collected annually from zimmi (non-Muslim) who live under Islamic rule.

${ }^{4}$ Tax imposed on land owned or occupied by force, violence, or land owned in peace.

${ }^{5}$ War loot.

${ }^{6}$ Non-Muslim's properties owned neither through the war nor by using war equipment. 
Zakat overflow occurred during the reign of Caliph Umar ibn Abdul Aziz as it was said that almost all of the people were not eligible to be the recipient of zakat. It has been narrated by Yahya ibn Said, who was a governor at the time. He said:

"I was sent by Umar ibn Abdul Aziz to collect zakat from Africa. After collecting it, I intended to give it to the poor people. However, I did not find one. Umar ibn Abdul Aziz has made all the people rich during his time. Finally, I decided to use the zakat fund to buy and emancipate slaves” [5].

Ufti imposed on the zimmi living in Muslim countries also were based on Islamic law. Prior to the reign of Caliph Umar ibn Abdul Aziz, ufti was imposed on the converted Muslim. During his reigns, the caliph removes the rules as it was conflicting with Islamic law. His fair decision has resulted in more zimmi converts to Islam. However, the situation resulted in complained from the governor as they said it will reduce the number of people who pay ufti. To deny the allegations, Caliph Umar ibn Abdul Aziz has answered with a letter as follows,

“Amma ba'd. Almighty Allah sent the Prophet Muhammad to call for the religion of all mankind, not as a tax or ufti collector" [6].

For zimmi living in poverty, the caliph did not imposed ufti on them. He did as was done by Hadrat Umar ibn Khattab r.a who allocates funds from baitulmal to help them [7]. His decision has strengthened the ties between the people and governor. Moreover, people's trust toward the governor also increased. The defamation against underfunded treasury when governor was instructed not to collect ufti from the converted non-Muslim was also eliminated by then [8].

The increased of zimmi who embraced Islam during the caliph time resulted in increased of zakat's payer. This occurs because the converted zimmi was rich, so they were able to pay zakat from the revenue of their enterprise in commercialize business and trades [3].

Prohibition of the sales of land bounded by land's tax also resulted in increased of kharaaj. Prohibition of the sales of the land was an ordered from the caliph which was in alignment to the sharia. Apart from the ban, Caliph Umar ibn Abdul Aziz also has been building drainage systems for irrigation purposes and roads to facilitate the process of exporting out the crops [3].

Elimination of several taxes in business also made many zimmi have desire to expand their business. These have resulted in increased of usyur, thus further increase the baitulmal funds during the caliph reign compared to other caliph before him.

However, the funds in form of a fifth of ghanimah and fa'ie were not much during his reign. It was because the caliph focused more on the paramount matter at that time, which was improving the people's and the country's condition. His short period of reign also did not gave him chance to carry out war but only to correspond via letters to kings and governors to embrace Islam.

\section{Stimulating and Boosting the Business Sector}

When the unreasonable taxes imposed previously has been removed by the Caliph Umar ibn Abdul Aziz, the price of agricultural products declined. This situation resulted in the increased demand for goods which ultimately make business more brisk than ever compared to the time before the unreasonable taxes were eliminated. Caliph Umar ibn Abdul Aziz also urged the governors to build facilities along the merchant's routes. Homes for transits were available and merchants were allowed to stay for one day and one night there. However, those who were sick were allowed to stay beyond the one day one night period. Muslim traders who lost, or whom having their merchandise stolen or were inflicting by other disaster were given helps too. All their losses will be guaranteed by the baitulmal. Those security and convenience indirectly has motivates traders and thus boost the business sector [9].

Apart from that, any provision for the traders was prohibited so that the traders will focused more on their trades rather than on the gift. Any merchants who were bankrupt, his debt will be settled by the baitulmal. Caliph Umar ibn Abdul Aziz done that as an encouragement for the traders to not gave up especially for those who were still new in business and trades sector. Standardization of weights and measurement were carried out earnestly by the caliph [5]. It was also a part of national law during his reign [3].

Caliph Umar ibn Abdul Aziz also prohibits the governors and close relatives of the royals from involved in business. He forbade it to provide healthy competition between businesses and to avoid changes of market price in their favors [3]. 


\section{Creating New Rules for the Agricultural Sector}

Caliph Umar ibn Abdul Aziz also implemented new regulations in the agricultural sectors. Amongst them was to prohibit the sale and purchase of land bound by lease ${ }^{7}$. This prohibition was issued by the caliph because he said it was not in Islamic law, unless the land was acquired through war. However, if the lease were to happen before the new rules were implemented, the owner can give alms in lieu of the lease instead [9].

Attention also was given to the farmers by eliminating the tax imposed on them. Various taxes imposed on the land's owner causing more of them to just leave their land unattended. Some of them have to sell their lands in order to avoid penalties and taxes. Moreover, people also avoid from having lands in order to escape the burden some taxes [5]. As a solution, the caliph eliminates the taxes to stimulate the growth of agricultural sector back.

Recovery of abandoned land also was made by Caliph Umar ibn Abdul Aziz by encouraging the people to open up new land to be developed or used for agricultural purposes. Furthermore, land tax was only imposed on land that produces revenue. Loans were also provided to encourage more agricultural production [9].

Himaa lands ${ }^{8}$ were not allowed to be solely owned by only a person or party only. Instead, the caliph ordered the land to be used wisely by the Muslims. Such land was more likely to have waqf status. However, the himaa land in the Naqii district was more dedicated for camels that come from alms or charity as the specialization has been determined by the Prophet [5].

Caliph Umar ibn Abdul Aziz also encourages his people to explore new land that has no owner. Moreover, the land taken from the previous governor which was left unattended and having unknown owners or heirs, were utilised accordingly by the caliph. The revenue from the lands was handed over to the baitulmal [3].

\section{Focus on General Funds Stored in the Baitulmal}

Caliph Umar ibn Abdul Aziz was very concerned regarding the public funds held in the baitulmal. He distributes the funds for the benefit of social protection. Among the efforts was to pay attention to the poor and needy. He always tried to solve problems and complained that was brought upon him. For example, the caliph received a letter from Fartunah as-Sauda's who was a slave to Dhi Ashbah. She wrote complains about the wall of her house that was low which make it prone to attack from bad guys and having her chicken stolen so often. Caliph Umar ibn Abdul Aziz immediately replied her letter and having a letter sent to Ayyub bin Syurahbil, who was his officials at Egypt, to raise the walls of Fartunah as-Sauda's house [5].

The caliph also pays off the debt of his people unless it was used for vices or sinful purposes [3]. The debts of citizens who were dead were paid using the baitulmal's fund [5]. The funds were also used to settle any fine that has been imposed on his people. As has been reported, the accumulated funds of baitulmal were so much that the governor of Kufah wrote to the caliph regarding the matter. The caliph then replied as follows:

"You have told me about the abundance of funds in the Baitulmal. You can use the funds to pay off debt of your war team which wasn't used for vices purposes or even for those who wanted to get married but did not have anything as dowry for the brides. Wassalam” [5].

Similar deals have been read at Kufah Mosque, which offering to pay the people’s debt [5] and wedding dowry for those who don't have the ability to provide dowry to the bride. All of the payment was to be taken from Baitulmal funds.

Large attention also was given to those who were paralyzed or suffered any illness. The caliph has given each of the paralyzed and ill people a slave to attend to their necessity. It was reported that during that time, each of sick people have slave attending to their needs and each blind person have slave to help them move around [5].

Muslim's prisoner of wars and slaves also were given attention by the caliph. Using the Baitulmal's funds, the caliph tried to free the captured Muslims and freed any slaves. Moreover, those who have involved in criminal cases and qisas also were protected by the caliph. The caliph once, has wrote letter to his governors not to bind Muslims prisoner in way that will make it more difficult for the prisoner to stand up for solat (pray). The prisoners were also given good care in terms of suitable foods and clothes either during summer or winter [1].

High salaries were given to the governor while the caliph has eliminated specific compensation and wages

${ }^{7}$ During the period of Abdul Malik ibn Marwan, al-Walid ibn Abd Malik, and Sulaiman ibn Abd Malik, there were people who asked the caliph for permission to buy land from ahl-zimmah. Permission was granted at that time with the condition that they have to pay a certain percentage of the selling value to baitulmal.

${ }^{8}$ Vacant land or farm, which were opened to be used as grazing land for livestock. 
that was practiced by the caliph before him. His own salary otherwise has been reduced. He did it so that the governors and officials became richer to prevent them from involving fraud [5].

\section{Vigilant with the Use of National Treasury}

Caliph Umar ibn Abdul Aziz was very frugal in the use of national treasury. He has different lamp when he was attending to the national and personal affairs. He has sent letter to Abu Bakr ibn Muhammad ibn Amru ibn Hazm, the governor of Medina, to not using the same candles which was provided to use to manage national affairs to light up the road if he was to be out at night for personal affairs. In addition, Caliph Umar ibn Abdul Aziz also has written to Suleiman, which also a governor of Medina, to prohibit wasteful use of paper. Those prohibitions were issued by the caliph to avoid waste and extravagance used of the baitulmal funds [5].

\section{Conclusions}

The wisdom of Umar ibn Abdul Aziz in managing the national treasury has made abundance of available baitulmal's funds. Despite the overflowing of treasury funds, the caliph however did not use it arbitrarily for himself or his family. The caliph and his family live in a poor condition, but people under his reign live a prosperous life. As narrated by a male descendent of Zaib ibn Khattab:

"Umar ibn Abdul Aziz ruled for two years and a half, i.e. 30 months. He did not die but after making us rich with riches galore, and he said, "divide this to anyone you think is poor". Umar continued to do that until he returned with the leftover funds. At that time, he no longer found a person entitled to receive zakat or states compensation that the fund has to be brought back to baitulmal. Umar ibn Abdul Aziz has made all his people become rich" [5].

Successful baitulmal's management during the period was not only depended on the strategies undertaken by Caliph Umar ibn Abdul Aziz. The success was also influenced by four main factors which the caliph regards as the pillar of power. The pillars were the caliph, the governor or district's ruler, the judges, and the officials of baitulmal [10]. The caliph has described that all the four factors were essential to create a prosperous country. Through a competent caliph, governor or district rulers, judges, and baitulmal's officer only the successful management of baitulmal's funds could be done.

Any financial institution such as baitulmal, state bank, world bank and so on, if were managed through solid strategies by competent and honest person could bring substantial benefits to the people and the country. It was proven by history as was prevailed during the reign of Caliph Umar ibn Abdul Aziz.

\section{References}

[1] Al-Ahli, S. and Aziz, A. (2010) Al-Khalifah Al-Zahid Umar bin Abd al-Aziz. Al-Hidayah Publication, Selangor.

[2] Ibn Abd Hakam, A. (2010) Al-Khalifah Adil Umar bin Abd al-Aziz: Khamis Khulafa al-Rasyidin. Alam Raya Enterprise, Kuala Lumpur.

[3] Al-Salabi, A.M.M. (2011) Khulafa al-Rasyidin wa al-Masoleh al-kabir Umar bin Abd al-Aziz: Wa Ma’alum al-Tajdid wa al-Islah al-Rasyidi ala Manhaj al-Nubuwwah. Al-Hidayah House of Bublisherd Sdn. Bhd., Selangor.

[4] Ibn Kathir, A.F.H. (2005) Al-Bidayahwa Al-Nihayah. Vol. 9, Dewan Bahasa dan Pustaka, Kuala Lumpur.

[5] Ibn Abd Hakam, A. (1994) Al-Khalifat al-Adil Umar Ibn Abd Aziz: Khamis al-Khulafa al-Rasyidin. Dar al-Fadilat, Kaherah.

[6] Ibn Sa’d, M. (n.da) Al-Tabaqat al-Kubra. Vol. 8, Dar Sadir, Berut.

[7] Ibn Sa’d, M. (n.db) Al-Tabaqat al-Kubra. Vol. 5, Dar Sadir, Berut.

[8] Abdeen, K.B. (2006) Al-Siyasah al-Iqtisadiyah wa al-Maliyah li Khalifah al-Rasyid Umar bin Abd Aziz. Dar al-Mamun li Nasyr wa al-Tauz, Berut.

[9] Ubyd, A. (1989) Al-’Amwal. Dar al-Syuruq, Berut.

[10] Khalid, K.M. (1985) Peri Hidup Khalifah Teladan. Pustaka Amani, Jakarta. 